\title{
“Endemism" Relative to Space, Time, and Taxonomic Level
}

\section{Citation}

Flynn, Lawrence J., Michèle E. Morgan, David Pilbeam, and John C. Barry. 2014. “'Endemism” Relative to Space, Time, and Taxonomic Level." Annales Zoologici Fennici 51 (1-2) (April): 245258. doi:10.5735/086.051.0223.

\section{Published Version}

doi:10.5735/086.051.0223

\section{Permanent link}

http://nrs.harvard.edu/urn-3:HUL.InstRepos:26507535

\section{Terms of Use}

This article was downloaded from Harvard University's DASH repository, and is made available under the terms and conditions applicable to Other Posted Material, as set forth at http:// nrs.harvard.edu/urn-3:HUL.InstRepos:dash.current.terms-of-use\#LAA

\section{Share Your Story}

The Harvard community has made this article openly available.

Please share how this access benefits you. Submit a story.

Accessibility 


\title{
"Endemism" relative to space, time, and taxonomic level
}

\author{
Lawrence J. Flynn ${ }^{1, *}$, Michèle E. Morgan², David Pilbeam \& John C. Barry ${ }^{1}$ \\ 1) Department of Human Evolutionary Biology, Harvard University, Cambridge, MA 02138, USA \\ ('coresponding author's e-mail: ljflynn@fas.harvard.edu) \\ 2) Peabody Museum, Harvard University, Cambridge, MA 02138, USA
}

Received 6 Aug. 2013, final version received 22 Nov. 2013, accepted 25 Nov. 2013

Flynn, L. J., Morgan, M. E., Pilbeam, D. \& Barry, J. C. 2014: "Endemism" relative to space, time, and taxonomic level. - Ann. Zool. Fennici 51: 245-258.

Faunal assemblages consist of immigrants, endemics and long-term residents; changes in proportions of these categories through time reflect general aspects of faunal stability and turnover. To study stability and change in the long biostratigraphic succession of Miocene terrestrial mammalian faunas recorded mainly in the Potwar Plateau Siwaliks of Pakistan, we distinguish long-term residents and assess new appearances as endemic vs. immigrant components. Our data represent the biogeography of the northern Indian subcontinent, but because neighboring areas of similar age are not as well known, virtually all species are found only there, and the proportion of the fauna that is immigrant is not apparent. We use preceding faunal assemblages to judge whether individual species might have originated there. We find many long-term residents in the Siwaliks, and of new species, most are immigrants and fewer are likely to have originated endemically. Siwalik rodents and artiodactyls show high rates of immigration for both during the early middle Miocene, followed by declining immigration but continuing residents. In the late middle Miocene both groups show stability, with a high proportion of long-term residents, and high endemism among rodents. In contrast, late Miocene rodent and artiodactyl patterns differ. Rodents decline in diversity but show increased immigration and new long-term residents; artiodactyls show turnover but then recover with many persisting residents.

\section{Introduction}

We are the beneficiaries of almost two hundred years of research on the terrestrial fossil record of the Siwalik deposits of the Indian subcontinent. Early explorers began to amass what became extensive collections of fossil vertebrates at the Geological Survey of India, Calcutta; the Natural History Museum, London; the American Museum of Natural History, New York; and the Peabody Museum of Natural History, New Haven, Connecticut. In addition to smaller samples else- where, modern research collections reside in Islamabad, at both the Geological Survey of Pakistan and the Pakistan Museum of Natural History, and presently in the Department of Human Evolutionary Biology, Harvard University, Cambridge, Massachusetts. It is the combined information held in and flowing from these collections that allows us to pose ever more sophisticated questions in evolutionary paleobiology. Our analysis is based on biostratigraphically controlled specimens in these collections, primarily those from the Potwar Plateau of northern Pakistan. 
We are increasingly able to describe the dynamics of faunal change in the Miocene of the Potwar Plateau. Taxa appear in the fossil record and disappear. What is the temporal pattern of appearances and disappearances? Where did new taxa originate? Were they immigrants or did they become emigrants? Understanding such patterns involves recognizing endemism. To some degree endemism characterizes Siwalik assemblages (Badgley \& Behrensmeyer 1995), but estimating the endemic proportions of assemblages is an imprecise task without fully developed systematic and biostratigraphic studies, and without clear definitions of terms.

The Indian subcontinent belongs to the Oriental Biogeographic Region. This vast Region spans $\sim 8000 \mathrm{~km}$ latitudinally, and includes significant faunal and floral variation from west to east (Lomolino et al. 2010), so the subcontinent itself corresponds to a subregion in the biogeographic hierarchy. It is unlikely that the fossil assemblages of the Potwar Plateau represent all parts of the subregion fully, so the Potwar record may be taken to represent a faunal province, that of northern Pakistan and adjacent India and Nepal, within the Indian subcontinent.

While being interested in faunal similarity, we must distinguish endemic taxa from immigrants. Defining areas of endemism remains controversial (Lomolino et al. 2010), but we apply Hausdorf's (2002) criterion of physical barriers to recognize the Indian subregion as an area of endemism. For this subregion, the barriers to faunal exchange are mountains to the west and north (Makran and other ranges in the southwest, Hindu Kush, Karakorum, Himalayas and Tibet to the north), the major N-S flowing rivers to the east (Brahmaputra, Irrawaddy, Salween) and intervening high terrain such as the Arakan Range, and the Indian Ocean around the peninsula. When we refer to endemism of Siwalik fossil species, we mean the geographically delimited area of the Indian subcontinent (an area larger than the faunal province, but smaller than the Oriental Region). Note that a geographic area of endemism contrasts with endemism recognized strictly by small range size ("range restriction" of Peterson \& Watson 1998).

"Endemic" means "occurring nowhere else" (Simpson 1965, Lomolino et al. 2010). Endemic status can be assessed and recognized in the present because one can observe biotas globally. Not so in the fossil record, and particularly not in the case of the Siwalik sequence: whereas the Siwalik biostratigraphic record is relatively complete from 18 to $6 \mathrm{Ma}$, fossil data adjacent to the Potwar Province are few, especially those that are well-calibrated. At the species level, nearly all records would be "endemic". Furthermore, judgment of endemism should flow from resolved phylogenies of species. Such studies are very uneven and most do not extend to the species level. To distinguish endemics from immigrants among newly appearing taxa, we turn to estimating likelihood of origination within the subregion of the Indian subcontinent; we pursue an assessment of endemism as an evolutionary process. This we attempt by reference to preceding assemblages: do close relatives precede the taxon in question? If so, then the species may have originated within the biogeographic subregion; if not, then the new arrival is considered an immigrant.

In dealing extensively with the phenomenon of endemism among living mammals, Simpson (1965) considered both the spatial (geographic) dimension and the taxonomic level under discussion: a species may be endemic to an area, while its genus is not because it is more widespread. Casanovas-Vilar et al. (2010) documented this phenomenon for lower taxonomic ranks of rodents, noting, as expected, that the Miocene of the Iberian Peninsula shows higher endemism at the species level than at the genus level. For the Miocene Siwaliks, we focus on the species level, but make some observations at higher taxonomic levels.

Time control is also crucial. At different times the same taxon, species or genus or higher, may show different geographical distributions. As an example, the fossil mouse genus Progonomys was endemic to South Asia at $12 \mathrm{Ma}$ (Jacobs \& Downs 1994); by 10 Ma the genus had spread throughout Eurasia and North Africa (Wessels 2009). The unit of time resolution constrains the distribution patterns one can perceive; coarser time-scales obscure fine details. The time dimension used in analyses - one hundred thousand years, one million, ten million - is of great importance for another reason. Historical analy- 
ses should document new arrivals in the fossil record relative to ages of other faunal elements, and relative to other biogeographic areas. Poor time control prevents discerning these relationships. For example, records are not yet sufficiently resolved to perceive whether sanithere ungulates migrated to or emigrated from the Indian subcontinent in the early Miocene (Barry et al. 2013).

\section{Material and methods}

The well-developed biostratigraphy of Siwalik Group strata in the Indian subcontinent is relatively continuous for the Miocene Epoch and is dated paleomagnetically (Barry et al. 2013). The record is densely represented by many fossil levels. Our goal is to assess Siwalik assemblages of the Potwar Plateau in northern Pakistan, and define times of change that reflect faunal turnover or events in community structure in the Indian subcontinent biogeographic subregion. We present a methodology to distinguish assemblage members that persist as long-term residents from new lineages that may have originated as immigrants or as endemics. Variation in these proportions within the long Siwalik record reflects events that may correlate to paleoecological or tectonic events.

\section{Definitions}

Endemic: Refers to exclusive presence of a taxon in a particular place at a particular time. Here we focus on both the species level and the inferred area of endemism of the Indian subcontinent that is represented primarily by the Siwalik fossil record. A newly present taxon in our record with a Potwar antecedent may be of endemic origin. If a species occurs outside the subregion at the same time, it is not endemic.

Immigrant: Refers to a newly present (sampled) taxon lacking probable antecedents or close congeners in the biogeographical subregion.

Resident: Refers to a taxon present in at least one successive sampled interval. Given the sampling-interval regime described here, this requires a minimum of two million years longevity.

Time slice: Successive time slices of the biostratigraphy are surveyed for species representation, here at two-million-year intervals. Each time slice analyzed represents about 200000 years; exceptions are the 15-16 Ma starting point for artiodactyls and the $6 \mathrm{Ma}$ end point that encompasses 300000 years (6-6.3 Ma) for both artiodactyls and rodents.

\section{Siwalik assemblages}

Although we drew on specimens from classical expeditions, our fundamental data base is the biostratigraphically-controlled collections of the Siwaliks amassed since 1973, primarily by the Y-GSP (Yale-Geological Survey of Pakistan, now Harvard-GSP) program on the paleontology of north and central Pakistan. These collections derive mainly from the Potwar Plateau, an area of $\sim 12000 \mathrm{~km}^{2}$, and are supplemented by material from other fossiliferous areas that have paleomagnetic control, all occurring in northern Pakistan.

We analyzed data as far as possible at the species level because that taxonomic unit recognizes the biologically relevant entities of past terrestrial communities of the area. We chose the two most species-rich higher taxa represented in Siwalik fossil collections: Rodentia and "Artiodactyla" (non-cetacean Cetartiodactyla). These groups are complementary both in their contrasting body mass ranges and in how they are collected. Because endemism is relative to taxonomic level, we also comment on endemism among genera.

Ages of Miocene localities are controlled and measured by stratigraphic superposition and paleomagnetic correlations, given a relatively complete and depositionally steady sedimentary record. To determine temporal ranges of taxa, we resolved the biostratigraphy as far as possible into 100000 year bins. Here we performed censuses of the fauna at two-million-year intervals using 200 000 year time slices (million year plus and minus 100000 years) to achieve more uniform data quality between intervals by pooling fossil assemblages. For rodents, taxonomic 
determinations follow Flynn and Wessels (2013), with updates from our current database, and data were drawn primarily from the Potwar Plateau of northern Pakistan. We added sites dated paleomagnetically from central Pakistan, but excluded data to the south in Sind Province. Ninety rodent species are recorded in this survey.

The Potwar database also records with precision the biostratigraphy of diverse artiodactyls. Current work resolves many lineages to the species level although, as for rodents, many informal designations (such as Suidae Y076) are still necessary to flag species, pending formal systematic analysis. The taxonomy was adjusted to be consistent with Barry et al. (2002, 2013) and Gentry et al. (2014), except where noted. Seventy-three species-level taxa are included in this survey.

Because the censuses were taken every two million years, but not between, it is not surprising that some familiar but short-lived Siwalik genera, such as Protoryx, are not netted here. Rather than pinpoint biostratigraphic appearances, the goal was to establish reference assemblages against which to evaluate subsequent assemblages. Two million years is near the mode observed for Siwalik small and large mammal species residence durations (Flynn et al. 1995). Therefore, most species would not appear in more than one or two censuses.

Consider two aspects of endemism with respect to space. First, if a taxon is "endemic" then it is not known to occur elsewhere. Unfortunately, in contrast to the relatively complete Siwaliks of the Indian subcontinent, other records are less complete. At the species level, nearly all Siwalik species might be considered endemic by the usual criteria: not known elsewhere. We therefore consider a second aspect of endemism: the likely area of origination of new taxa. Given a new arrival, what is the likelihood that it arose within its biogeographic subregion or province (endemically)? The alternative is that it arose in another area and immigrated. In our framework we considered endemic a taxon arising within the Indian subcontinent (and known only from there). If it was preceded by a closely-related taxon, a newly-appearing species may be considered endemic. "Endemism" herein is considered narrowly; a taxon arising to the east in southeast Asia would not be endemic to the Indian subcontinent subregion. The long record offers a basis for judgment of newly appearing species. In the absence of phylogenetic trees, we used preceding congeneric species as proxies for close relatives.

For the Siwaliks of northern Pakistan our goal was to assess new Miocene appearances as endemics or immigrants. We performed repeated assessments throughout the biostratigraphy by reference to preceding assemblages; one cohort of contemporaneous taxa is the frame of reference for the succeeding assemblage. In the following we tabulate data for rodents and artiodactyls, showing censuses every two million years and annotating taxa as immigrants (I), endemics (E), or residents (R). Once a species appears as an immigrant or an endemic, any later record is considered a resident.

\section{Results}

\section{Rodentia}

We recorded rodent occurrences for time-slices centered at successive two-million-year intervals, beginning at $22 \mathrm{Ma}$ and ending at $6 \mathrm{Ma}$ (Tables 1 and 2). The time slices embrace one to several localities, and some slices are dominated by single very fossiliferous sites. Samples are small at the beginning and end of the record, and for the $6 \mathrm{Ma}$ slice, we used a site dated to 6.3 Ma. The first records at $22 \mathrm{Ma}$ are few, and with little information on whether the taxa might be endemic, they are simply recorded as present (X). Other than " $\mathrm{X}$ " for 22 Ma occurrences, each species is judged for its first record as either an immigrant (I) or an endemic (E); later repeated presences are noted as residents (R). Of 136 records, nearly $40 \%$ (51) are residents.

Of the 90 species included in this survey, five are already present at $22 \mathrm{Ma}$, and 85 appear subsequently. Of the 85 species, $38(45 \%)$ are endemic in origin, and $47(55 \%)$ appear as immigrants. In comparison, at the taxonomic level of the genus, 12 genera are unknown from anywhere else globally when they first occur on the Indian subcontinent (asterisks in Table 1), so roughly only a fourth of the total number of 
Table 1. Occurrences of Siwalik rodents at time slices (ages in Ma).

\begin{tabular}{|c|c|c|c|c|c|c|c|c|c|}
\hline Family/Species & 22 & 20 & 18 & 16 & 14 & 12 & 10 & 8 & 6 \\
\hline \multicolumn{10}{|l|}{ Sciuridae } \\
\hline Pteromyinae indet. & & I & $\mathrm{R}$ & $\mathrm{R}$ & & & & & \\
\hline Aliveria sp. & & & & 1 & & & & & \\
\hline cf. Oriensciurus sp. & & I & & & & & & & \\
\hline Oriensciurus sp. & & & I & & & & & & \\
\hline Funambulus sp.* & & & & I & $\mathrm{R}$ & $\mathrm{R}$ & $\mathrm{R}$ & & \\
\hline Sciurotamias large & & & & & & & $E$ & $\mathrm{R}$ & \\
\hline Sciurotamias small & & & & & 1 & $\mathrm{R}$ & & & \\
\hline Eutamias "pre-urialis" & & & & & I & & & & \\
\hline Eutamias urialis & & & & & & $E$ & & & \\
\hline Tamias unnamed & & & & & & & I & & \\
\hline cf. Tamiops sp. & & I & & & & & & & \\
\hline Tamiops sp. & & & 1 & & & & & & \\
\hline Tamiops small & & & & & I & $\mathrm{R}$ & $\mathrm{R}$ & & \\
\hline Tamiops large & & & & & & $\mathrm{E}$ & $\mathrm{R}$ & $\mathrm{R}$ & \\
\hline Atlantoxerus sp. & & & & & 1 & & & & \\
\hline Heteroxerus sp. & & & & & 1 & & & & \\
\hline Callosciurus sp. & & & & & 1 & & & & \\
\hline Dremomys sp. & & & & & i & $\mathrm{R}$ & & & \\
\hline Dremomys large & & & & & & & $E$ & $\mathrm{R}$ & \\
\hline cf. Ratufa sp. & $\mathrm{x}$ & & & & & & & & \\
\hline Ratufa sp. & & & I & & & & & & \\
\hline Ratufa sylva & & & & & & & 1 & & \\
\hline \multicolumn{10}{|l|}{ Ctenodactylidae } \\
\hline Prosayimys unnamed ${ }^{*}$ & $x$ & & & & & & & & \\
\hline Sayimys baskini & & & $\mathrm{E}$ & $\mathrm{R}$ & & & & & \\
\hline Sayimys intermedius & & 1 & $\mathrm{R}$ & $\mathrm{R}$ & & & & & \\
\hline Sayimys large sp. & & & & I & & & & & \\
\hline Sayimys sivalensis & & & & & $\mathrm{E}$ & & & & \\
\hline Sayimys chinjiensis & & & & & & $\mathrm{E}$ & & & \\
\hline Sayimys "sp. B" & & & & & & I & & & \\
\hline \multicolumn{10}{|l|}{ Hystricidae } \\
\hline Sivacanthion complicatus* & & & & & & I & & & \\
\hline Hystrix sivalensis & & & & & & & & 1 & $\mathrm{R}$ \\
\hline \multicolumn{10}{|l|}{ Diatomyidae } \\
\hline Diatomys shantungensis & & I & & & & & & & \\
\hline Diatomys chitaparwalensis & & & $\mathrm{E}$ & & & & & & \\
\hline Marymus sp.* & & $E$ & & & & & & & \\
\hline \multicolumn{10}{|l|}{ Thryonomyidae } \\
\hline Kochalia sp.* & & & 1 & $\mathrm{R}$ & & & & & \\
\hline Kochalia geespei & & & & & $\mathrm{E}$ & $\mathrm{R}$ & & & \\
\hline Paraulacodus indicus & & & & & & I & & & \\
\hline \multicolumn{10}{|l|}{ Gliridae } \\
\hline Myomimus sumbalenwalicus & & & & & 1 & $\mathrm{R}$ & & & \\
\hline Myomimus unnamed & & & & & & & $\mathrm{E}$ & & \\
\hline cf. Peridyromys sp. & & & & & & & 1 & & \\
\hline cf. Microdyromys sp. & & & & & & & & 1 & \\
\hline Dryomys sp. & & & & & & & & I & \\
\hline \multicolumn{10}{|l|}{ Spalacidae } \\
\hline Prokanisamys sp. & $x$ & & & & & & & & \\
\hline Prokanisamys arifi & & $\mathrm{E}$ & $\mathrm{R}$ & & & & & & \\
\hline cf. Prokanisamys arifi & & & & $E$ & $\mathrm{R}$ & $\mathrm{R}$ & & & \\
\hline Prokanisamys major & & & $\mathrm{E}$ & $\mathrm{R}$ & & & & & \\
\hline Kanisamys potwarensis* & & & & & I & & & & \\
\hline Kanisamys indicus & & & & 1 & $\mathrm{R}$ & $\mathrm{R}$ & & & \\
\hline
\end{tabular}


Table 1. Continued.

\begin{tabular}{|c|c|c|c|c|c|c|c|c|c|}
\hline Family/Species & 22 & 20 & 18 & 16 & 14 & 12 & 10 & 8 & 6 \\
\hline Kanisamys nagrii & & & & & & & $\mathrm{E}$ & & \\
\hline Kanisamys sivalensis & & & & & & & & $E$ & \\
\hline Rhizomyides punjabiensis* & & & & & & & I & & \\
\hline Rhizomyides sp. & & & & & & & & $E$ & \\
\hline Rhizomyides sivalensis & & & & & & & & & $E$ \\
\hline Miorhizomys tetracharax & & & & & & & & I & \\
\hline Miorhizomys choristos & & & & & & & & I & \\
\hline cf. Miorhizomys pilgrimi & & & & & & & & I & \\
\hline \multicolumn{10}{|l|}{ Cricetidae } \\
\hline Primus microps* & & I & & & & & & & \\
\hline Spanocricetodon khani & & $E$ & & & & & & & \\
\hline Spanocricetodon sp. & $X$ & $\mathrm{R}$ & & & & & & & \\
\hline Democricetodon sp. X & $X$ & $\mathrm{R}$ & & & & & & & \\
\hline Democricetodon sp. A & & & $E$ & $\mathrm{R}$ & $\mathrm{R}$ & & & & \\
\hline Democricetodon sp. B-C & & & & $E$ & $\mathrm{R}$ & $\mathrm{R}$ & $\mathrm{R}$ & & \\
\hline Democricetodon kohatensis & & & & $E$ & $\mathrm{R}$ & $\mathrm{R}$ & $\mathrm{R}$ & & \\
\hline Democricetodon sp. E & & & & & $E$ & $\mathrm{R}$ & $\mathrm{R}$ & & \\
\hline Democricetodon sp. F & & & & & & $E$ & $\mathrm{R}$ & $\mathrm{R}$ & \\
\hline Democricetodon sp. G & & & & & & $E$ & $\mathrm{R}$ & & \\
\hline Democricetodon sp. $\mathrm{H}$ & & & & & & $E$ & $\mathrm{R}$ & $\mathrm{R}$ & \\
\hline \multicolumn{10}{|l|}{ Muridae } \\
\hline Dakkamys sp. & & & & & I & & & & \\
\hline Dakkamys barryi & & & & & & $E$ & & & \\
\hline Dakkamys asiaticus & & & & & & $E$ & $\mathrm{R}$ & & \\
\hline Paradakkamys chinjiensis* & & & & & & I & $\mathrm{R}$ & & \\
\hline Punjabemys mikros* & & & & 1 & $\mathrm{R}$ & & & & \\
\hline Punjabemys downsi & & & & & $E$ & & & & \\
\hline Megacricetodon aguilari & & & I & $\mathrm{R}$ & $\mathrm{R}$ & & & & \\
\hline Megacricetodon mythikos & & & & & $E$ & & & & \\
\hline Myocricetodon sivalensis & & & & I & $\mathrm{R}$ & & & & \\
\hline Mellalomys lavocati & & & & I & $\mathrm{R}$ & & & & \\
\hline Mellalomys perplexus & & & & & & $E$ & & & \\
\hline Abudhabia pakistanensis & & & & & & & & I & \\
\hline Potwarmus primitivus & & & & I & $\mathrm{R}$ & & & & \\
\hline Antemus chinjiensis* & & & & & $\mathrm{E}$ & & & & \\
\hline Progonomys hussaini & & & & & & $E$ & & & \\
\hline Progonomys sp. & & & & & & & $E$ & & \\
\hline Karnimata sp.* & & & & & & & $E$ & & \\
\hline Progonomys debruijni & & & & & & & & $\mathrm{E}$ & \\
\hline Karnimata darwini & & & & & & & & $E$ & \\
\hline Parapodemus sp. & & & & & & & & 1 & \\
\hline Mus auctor & & & & & & & & & 1 \\
\hline Karnimata huxleyi & & & & & & & & & $E$ \\
\hline Parapelomys robertsi & & & & & & & & & I \\
\hline
\end{tabular}

* Genera provisionally considered to originate endemically in the Indian subcontinent.

Table 2. Summary for rodent occurrences.

\begin{tabular}{lrrrrrrrrrr}
\hline Status & $20 \mathrm{Ma}$ & $18 \mathrm{Ma}$ & $16 \mathrm{Ma}$ & $14 \mathrm{Ma}$ & $12 \mathrm{Ma}$ & $10 \mathrm{Ma}$ & $8 \mathrm{Ma}$ & $\begin{array}{r}\text { Ma } \\
\text { records }\end{array}$ \\
\hline Immigrant & 6 & 5 & 8 & 10 & 4 & 4 & 8 & 2 & 47 \\
Endemic & 3 & 4 & 3 & 6 & 10 & 6 & 4 & 2 & 38 \\
Resident & 2 & 3 & 7 & 11 & 11 & 11 & 5 & 1 & 51 \\
Total & 11 & 12 & 18 & 27 & 25 & 21 & 17 & 5 & 136 \\
\hline
\end{tabular}


genera could be considered endemic; we do not assert that all in fact arose in the subcontinent.

It is important to explain how we judged the plausibility of endemism for individual species. Squirrels (Sciuridae) are rare in the Indian subcontinent until the middle Miocene. Therefore, early squirrel occurrences are preceded by no records that could be construed as ancestral lineages and all are interpreted as immigrants. Pteromyines are an exception to the rule of tracking taxa at the species level; the group, probably comprising more than one species, is encountered only in the early Miocene. At $14 \mathrm{Ma}$ many new taxa appear, partly as a function of an improved record, but likely representing immigration (I), even if all immigration events were not simultaneous. Some species (R) persist into subsequent intervals. Eutamias urialis appears by $12 \mathrm{Ma}$ and, being very similar to an older congener, is regarded as having originated endemically (E). Following the rule of being preceded by congeners, a new Tamiops species and, later at $10 \mathrm{Ma}$, a Sciurotamias and a Dremomys species are recorded as endemics. For Late Miocene Ratufa sylva we made the conservative decision that the species may not have arisen endemically because its congener is eight million years older and morphologically not very similar (perhaps not best interpreted as congeneric), and because the genus Ratufa was and is widespread (fossil records in Thailand and South China [Mein \& Ginsburg 1997, Qiu \& Ni 2005]).

Among gundis (Table 1) Sayimys may well be derived from Prosayimys by $\sim 20 \mathrm{Ma}$, but because $S$. intermedius occurs elsewhere outside Pakistan [type specimen from Saudi Arabia, Şen and Thomas (1979)], it may be an immigrant. Later species of Sayimys (14 and $12 \mathrm{Ma}$ ) appear to be endemics. Hystricids appear abruptly as immigrants, as does Diatomys (type species from China). However, D. chitaparwalensis conceivably evolved in the Indian subcontinent, and Marymus sp. (from Banda Daud Shah, west of the Potwar Plateau) is an endemic derivative of Marymus dalanae; both are early Miocene (Flynn 2007). The African cane rat family Thryonomyidae occurs in Pakistan via two immigration events with the more primitive Kochalia sp. immigrating $(\sim 18 \mathrm{Ma})$, before the derived Paraulacodus indicus ( 12 Ma; Flynn \& Win- kler 1994). Both have African sister taxa. The mid-Miocene K. geespei appears to be endemic.

Dormice (Gliridae) appear abruptly in the Indian subcontinent. Absent from all early Miocene localities, including a rich site dating to 14.3 Ma, dormice are encountered at many localities 13.8 Ma in age and younger. There is an older, diverse record of dormice in Europe and elsewhere. Middle Miocene and some later Siwalik dormice are probably immigrants.

Muroid rodents, the most species-rich group in the Siwaliks, are represented by three families (Table 1). The radiation of primitive bamboo rats (rhizomyines) begins with Prokanisamys, which is followed by late early Miocene endemic congeners. Kanisamys indicus and $K$. potwarensis (16 and $14 \mathrm{Ma}$ ), and Rhizomyides later at 10 $\mathrm{Ma}$, could be endemic derivatives but are tallied here as immigrants because they differ morphologically from Prokanisamys and could have evolved elsewhere in southern Asia. Later species of Kanisamys and Rhizomyides resemble their predecessors and are scored as endemics. Species of Miorhizomys appear abruptly after $10 \mathrm{Ma}$ and are considered immigrants, although some of the half dozen short-lived late Miocene members of the genus not captured in the censuses may be endemic products.

Among Cricetidae, early Primus and Spanocricetodon had no clear predecessors, but later S. khani (20 Ma) could be endemic. Early Democricetodon appears at the same time as congeners in Turkey and Greece and the Junggar Basin, China (see Flynn et al. 2013). The subsequent radiation in the Indian subcontinent is regarded as endemic. Some of these species are long-lived for rodents. Murids, including gerbils, diversify during the middle Miocene. First appearances of lineages ( $14 \mathrm{Ma})$ are recorded as immigrants. Again, subsequent congeners such as species of Dakkamys at $12 \mathrm{Ma}$ are considered endemics. Potwarmus is recorded as an immigrant, but there is a strong case (Jacobs \& Downs 1994) for derivation of Antemus ( 14 Ma) and then Progonomys (12 Ma) from Potwarmus, so these are taken as successive endemics of a complex, long resident lineage. Mus auctor ( $\sim \mathrm{Ma})$ conceivably evolved from this same lineage, but conservatively is listed as an immigrant because early Pliocene congeneric species occur else- 
where. Late Miocene Karnimata species appear to be endemics, but Parapodemus and possibly Parapelomys could have originated elsewhere.

\section{Artiodactyla}

Diversification of the ruminants is largely a middle to late Miocene phenomenon. As a starting point to assess endemism of later occurrences, we begin with specimens recovered in the ca. 16 to $15 \mathrm{Ma}$ interval (generally unproductive localities, so several are lumped here). As for rodents, initial occurrences are designated by " $\mathrm{X}$ " to serve as a reference for later time slices. There are 11 initial occurrences, including two Bovidae (Table 3). Artiodactyls are surveyed for five subsequent two million year slices, the last of which includes sites of 6.0 to $6.3 \mathrm{Ma}$ age. We record 73 species-level taxa, with six of the 11 in the first interval found only there. The five subsequent time slices render 96 records, of which $34(35 \%)$ occurrences are scored as residents. Of the 62 first occurrences, 25 (40\%) are recorded as endemics, and $37(60 \%)$ are immigrants.

Several suoids and anthracotheres are recorded in the early middle Miocene (16-15 Ma) Siwaliks. Listriodon guptai is present and succeeded by a species that evolved endemically. Other suids of this age (14 Ma) are judged as immigrants. The anthracothere genera Microbunodon and Merycopotamus initiate long lineages including later endemic species in each. The late Miocene hippopotamid Hexaprotodon is an immigrant.

The tragulid genera Dorcabune and Dorcatherium occur early in the Siwaliks (Table 3).

Table 3. Occurrences of Siwalik artiodactyl taxa at time slices (ages in Ma).

\begin{tabular}{|c|c|c|c|c|c|c|}
\hline Family/Species & $16-15$ & 14 & 12 & 10 & 8 & 6 \\
\hline \multicolumn{7}{|l|}{ Sanitheriidae } \\
\hline Sanitherium schlagintweiti & $x$ & $\mathrm{R}$ & & & & \\
\hline \multicolumn{7}{|l|}{ Suidae } \\
\hline Sivameryx palaeindicus & $\mathrm{x}$ & & & & & \\
\hline Listriodon guptai & $\mathrm{x}$ & & & & & \\
\hline Listriodon pentapotamiae & & $\mathrm{E}$ & $\mathrm{R}$ & & & \\
\hline Conohyus sindiensis & & 1 & $\mathrm{R}$ & & & \\
\hline Hyotherium pilgrimi & & 1 & $\mathrm{R}$ & & & \\
\hline Propotamochoerus hysudricus & & & & I & $\mathrm{R}$ & $\mathrm{R}$ \\
\hline Hippopotamodon sivalense & & & & 1 & $\mathrm{R}$ & \\
\hline Suidae, Y076 & & & I & & & \\
\hline Suidae, tiny, Y311 & & & & 1 & & \\
\hline Schizochoerus gandakasensis & & & & I & & \\
\hline ? Sus sp. & & & & & & I \\
\hline \multicolumn{7}{|l|}{ Anthracotheriidae } \\
\hline Microbunodon silistrense & $x$ & $\mathrm{R}$ & $\mathrm{R}$ & & & \\
\hline Microbunodon milaensis & & & & E & & \\
\hline Merycopotamus nanus & $\mathrm{X}$ & $\mathrm{R}$ & $\mathrm{R}$ & & & \\
\hline Merycopotamus medioximus & & & & $E$ & & \\
\hline Merycopotamus large sp. & & & & & $E$ & \\
\hline Merycopotamus dissimilus & & & & & & $E$ \\
\hline Sivameryx palaeindicus & $\mathrm{x}$ & $\mathrm{R}$ & & & & \\
\hline \multirow{2}{*}{\multicolumn{7}{|c|}{ Tragulidae }} \\
\hline & & & & & & \\
\hline Dorcabune sp. & $x$ & & & & & \\
\hline Dorcabune anthracotherioides & & & $E$ & & & \\
\hline Dorcabune unnamed & & $\mathrm{E}$ & & & & \\
\hline Dorcabune nagrii & & & & $E$ & $\mathrm{R}$ & \\
\hline Dorcatherium sp. & $\mathrm{x}$ & & & & & \\
\hline Dorcatherium minimus & & $\mathrm{E}$ & $\mathrm{R}$ & $\mathrm{R}$ & & \\
\hline Dorcatherium small sp. complex & & $\mathrm{E}$ & & & & \\
\hline
\end{tabular}


Table 3. Continued.

\begin{tabular}{|c|c|c|c|c|c|c|}
\hline Family/Species & $16-15$ & 14 & 12 & 10 & 8 & 6 \\
\hline Dorcatherium minus & & $E$ & $\mathrm{R}$ & & & \\
\hline Dorcatherium very small sp. & & $E$ & $\mathrm{R}$ & & & \\
\hline Dorcatherium majus & & & & $E$ & $\mathrm{R}$ & \\
\hline Dorcatherium sp. D & & & & $E$ & $\mathrm{R}$ & \\
\hline Dorcatherium Y270 & & & & $E$ & & \\
\hline Dorcatherium Y373 & & & & & $E$ & \\
\hline Dorcatherium unnamed & & & & & & $E$ \\
\hline Tragulidae, new & & & & & & I \\
\hline Pecora incert. sedis & & & & & & \\
\hline Progiraffa sp. & $x$ & & & & & \\
\hline \multicolumn{7}{|l|}{ Giraffidae } \\
\hline Giraffokeryx punjabiensis & & I & $\mathrm{R}$ & & & \\
\hline Bramatherium megacephalum & & & & I & $\mathrm{R}$ & \\
\hline New Sivathere & & & I & & & \\
\hline Giraffa punjabiensis & & & & & l & $\mathrm{R}$ \\
\hline \multicolumn{7}{|l|}{ Bovidae } \\
\hline Boselaphini, very small & $X^{*}$ & $\mathrm{R}$ & & & & \\
\hline cf. Elachistocerus khauristanensis & & I & $\mathrm{R}$ & & & \\
\hline Elachistocerus khauristanensis & & & & $E$ & $\mathrm{R}$ & \\
\hline Strepsiportax unnamed & & I & & & & \\
\hline Strepsiportax gluten & & & $E$ & & & \\
\hline Eotragus unnamed & & I & & & & \\
\hline Sivoreas eremita & & I & $\mathrm{R}$ & & & \\
\hline Helicoportax praecox & & I & $\mathrm{R}$ & & & \\
\hline Sivaceros gradiens & & & $\mathrm{E}$ & & & \\
\hline Sivaceros unnamed & & I & & & & \\
\hline Selenoportax vexillarius & & & & I & & \\
\hline Selenoportax giganteus & & & & & $\mathrm{E}$ & \\
\hline Bovidae, very large & & & & & 1 & \\
\hline Miotragocerus pilgrimi & & & & I & & \\
\hline Miotragocerus punjabicus & & & & & $\mathrm{E}$ & $\mathrm{R}$ \\
\hline Tragoportax salmontanus & & & & & I & $\mathrm{R}$ \\
\hline Pachyportax sp. & & & & & & I \\
\hline Tragelaphini gen. \& sp. & & & & & & I \\
\hline Hippotragini gen. \& sp. & & & & & & I \\
\hline Bovidae Y535 & & & & & I & \\
\hline Gazella sp. & & & I & & & \\
\hline Gazella lydekkeri & & & & $E$ & $\mathrm{R}$ & $\mathrm{R}$ \\
\hline Gazella large sp. & & & & $\bar{E}$ & & \\
\hline Dorcadoxa porrecticornis & & & & $\mathrm{l}$ & $\mathrm{R}$ & \\
\hline Kobus sp. A & & & & & I & \\
\hline Kobus sp. B & & & & & & $E$ \\
\hline ?Antilopinae, small sp. & & & & & I & $\mathrm{R}$ \\
\hline Prostrepsiceros vinayaki & & & & & I & \\
\hline Hypsodontinae, unidentified & $\mathrm{X}$ & & & & & \\
\hline Hypsodontus pronaticornis & & & I & & & \\
\hline Turcocerus grangeri & & & I & $\mathrm{R}$ & & \\
\hline Antilopini gen. \& sp. & & I & & & & \\
\hline Kubanotragus sokolovi & & I & & & & \\
\hline
\end{tabular}

* The record of a boselaphine at 16-15 Ma is unresolved, but possibly the same as its successor.

Dorcabune is Asian, with possible late Miocene occurrences in Greece and elsewhere. Dorcatherium is noted in Africa, Europe, and Asia, but how closely these populations are related to Siwalik taxa remains to be determined (Rössner 2007). Subsequent to the early record of each 
genus, we mark each newly-appearing Siwalik tragulid species as endemic in origin. At the genus level, Dorcatherium is highly speciose with at least 10 species present in the Siwalik record. Dorcabune is less common and less speciose. Giraffids lack closely related predecessors in South Asia so Giraffokeryx at $14 \mathrm{Ma}$ is considered to be an immigrant. Bramatherium (10 Ma) is closely related to Giraffokeryx and is a putative descendant; however, as a separate genus it is recorded here as immigrant. The late Miocene Giraffa and an unnamed sivathere are also considered immigrants.

Bovidae are rare in the early Miocene. By contrast they are diverse throughout middle and late Miocene horizons. At about $14 \mathrm{Ma}$, many immigrants enter the biogeographic area. Some persist at $12 \mathrm{Ma}$ or are represented by closely related species, for example Strepsiportax gluten replaces its congener (Table 3). Selenoportax and Miotragocerus are examples of new immigrants succeeded at 8 Ma by similar species, which are considered endemics (see also Gentry et al. 2014). We consider Gazella and Kobus as immigrants when they first appear in the Siwalik record, but they initiate late Miocene endemic successor species.

\section{Discussion}

\section{Endemism}

Recognition of endemism in the fossil record by applying known areas of occurrence exclusively risks an inflated estimation of endemism. This may be a factor in the very high proportions of endemics seen by Costeur (2009) among ungulates in neighboring regions of Europe during the Neogene. Given a high-quality fossil record, we take a different approach, attempting to discern origins of taxa as endemic $v s$. immigrant within a biogeographic subregion.

Herein we evaluated species appearances in the Miocene Siwalik record of Pakistan, assessing the likelihood that each originated as an endemic or immigrant, while noting that evaluation of endemism must be done in relation to clearly defined concepts. Firstly, being interested in Siwalik assemblages as indicators of past com- munities, we focused on the species level. Secondly, endemism refers to exclusive occurrence in the Indian subcontinent subregion; adjacent areas such as the southeast Asia subregion of the Oriental Region are excluded. Thirdly, endemism was evaluated in the framework of time: we focused on how a species appears in the record - what is the likelihood of endemism given reference to a preceding assemblage. The rule followed here is that a new arrival is considered an immigrant if no closely related predecessor is represented in the previous time slice. Close relationship may be based on systematic study of that lineage, or on earlier presence of a similar congener.

We realize that this process for assessing endemism involves error, but we see counteracting sources of error. The assumption that a new Siwalik record, if preceded by a congener, would have evolved in our biogeographic subregion could be falsified if an unknown sister species were found to occur outside the subregion. This could be the case for some later species of Dorcatherium, which we have taken to originate within the Indian subcontinent subregion; future study could reveal a sister species outside the area, increasing likelihood of immigration into the Potwar Plateau. On the other hand, successive Siwalik species tentatively recognized as different genera in fact may be local lineages, yielding a false impression of immigration. This may be the case for later glirids, currently under study and presenting advanced traits, so assigned to different genera based on morphological grade. On balance, we may overestimate the contribution by endemics, yet we are unable to quantify this uncertainty, which we currently consider minor.

\section{Time slices}

To provide a basis of analysis of community change, successive assemblages at two-millionyear time slices were compared. Species appearing for the first time were judged as either endemics or immigrants. Once established a new arrival becomes a resident and is recorded as such if it survives into a subsequent time slice. Given short residence times of species and two million years between time slices, few long-term residents span multiple intervals. Two million years is close to 
modal values observed for Siwalik species residence, and similar durations are cited by Van der Meulen et al. (2005) for rodents of the Spanish Miocene and by Raia et al. (2011) for NOW database ruminants (http://www.helsinki.fi/science/ now/). The perceived proportion of long-term residents must obviously depend on the interval between time slices: the longer the interval, the fewer the long-term residents.

Utilizing these definitions, proportions of assemblages judged to be endemics vs. immigrants, or of long residence time were found to be similar for small and large mammals (Tables 2 and 4). Over one third of rodents and of artiodactyls in faunal assemblages were longterm residents. Overall, immigrants were more numerous than endemics: about $55 \%$ of the 85 new rodent appearances were immigrants, and $60 \%$ of the 62 newly recorded artiodactyls immigrated. Endemics were many, but less than half overall. The proportions of immigrants to endemics are not constant over time and are reviewed here. Acknowledging that record quality varies across Siwalik time slices, the following overview focuses on better-represented intervals. Proportions in the youngest rodent census (five species), for instance, have little meaning.

The early part of the rodent record (Fig. 1A) shows growing species richness with immigrants outnumbering endemics. In particular, the number of immigrants at $16 \mathrm{Ma}$, in contrast to endemics, is significant (binomial test: $p=$ 0.033). At $14 \mathrm{Ma}$ this trend continues, but by this time the species-rich fauna includes many residents. In contrast, the $12 \mathrm{Ma}$ fauna has high levels of endemics as compared with immigrants (binomial test: $p=0.029$ ) as well as many residents. The $10 \mathrm{Ma}$ fauna is less species-rich, with fewer endemic appearances and many persisting residents. The $8 \mathrm{Ma}$ fauna records new turnover and a drop in continuing residents. The propor-
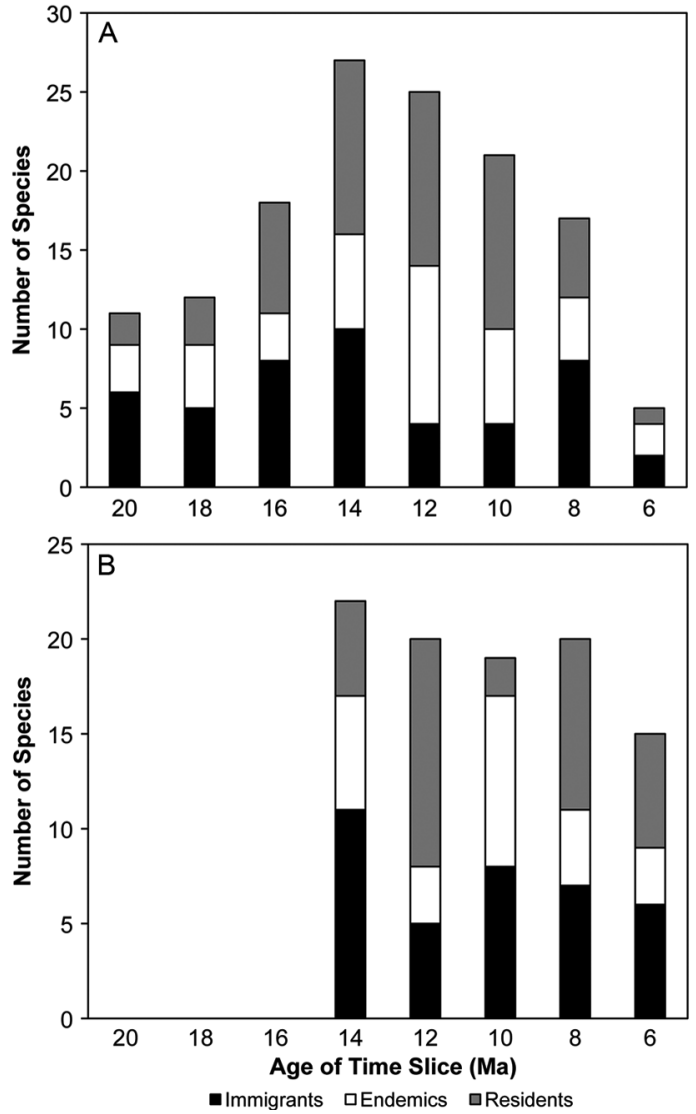

Fig. 1. Time slice censuses of (A) rodent and (B) artiodactyl species in Siwalik assemblages, with slices centered at two-million-year intervals. Each census records Immigrants, Endemics, and Residents. Immigrants are positioned at the bottom of each column to emphasize changes in that category. Numbers of species are recorded for rodents (1A, above; $20 \mathrm{Ma}$ to $6 \mathrm{Ma}$ intervals) and for artiodactyls (1B, below, 14 to $6 \mathrm{Ma})$.

tion of new species (immigrants plus endemics) $v s$. residents is significantly different from that expected under the binomial distribution $(p=$ $0.025)$. Long-term trends include increasing species richness through the middle Miocene, many immigrants through $14 \mathrm{Ma}$, a large proportion of

Table 4. Summary for artiodactyl occurrences.

\begin{tabular}{lccccrr}
\hline Taxon status & $14 \mathrm{Ma}$ & $12 \mathrm{Ma}$ & $10 \mathrm{Ma}$ & $8 \mathrm{Ma}$ & $6 \mathrm{Ma}$ & Total records \\
\hline Immigrant & 11 & 5 & 8 & 7 & 6 & 37 \\
Endemic & 6 & 3 & 9 & 4 & 9 & 25 \\
Resident & 5 & 12 & 2 & 21 & 6 & 34 \\
Total & 22 & 20 & 18 & & 96 \\
\hline
\end{tabular}



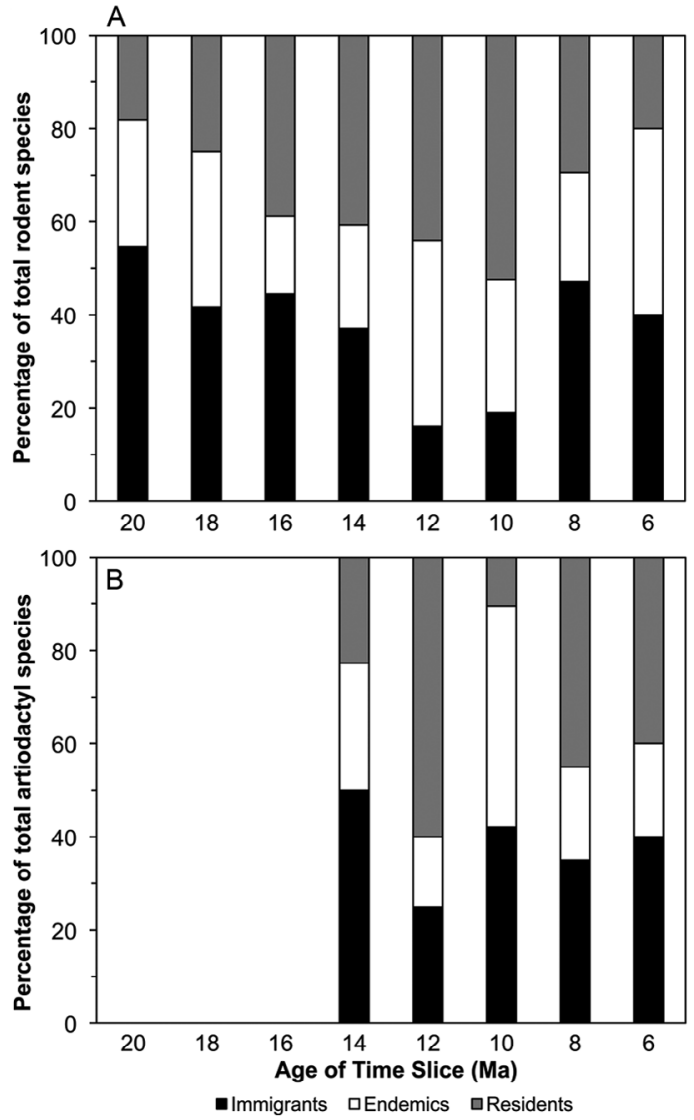

Fig. 2. Time slice censuses of Siwalik (A) rodents and (B) artiodactyls, with proportions of Immigrants, Endemics, and Residents shown as percentages of total assemblages. Shading patterns as in Fig. 1. Compared over five time slices, $14 \mathrm{Ma}$ to $6 \mathrm{Ma}$, the rodents (Fig. 2A) and artiodactyls (Fig. 2B) show similar trends in the middle Miocene, but divergent patterns during the late Miocene.

long-term residents in the middle Miocene coinciding with a peak in endemics at $12 \mathrm{Ma}$, and turnover by $8 \mathrm{Ma}$ with few surviving lineages.

For artiodactyls (Fig. 1B) the peak in immigrants occurs at $14 \mathrm{Ma}$, when apparently many taxa, especially bovids, are first recorded in the Siwaliks. The immigrant plus endemic originations at this time $v s$ residents is significant (binomial test: $p=0.002$ ). By the next time slice, $12 \mathrm{Ma}$, many lineages can be scored as residents, indicating late middle Miocene faunal stability. The following $10 \mathrm{Ma}$ interval records highs in both endemic and immigrant species appearances but unusually few continuing residents, reflecting significant faunal change between 12 and $10 \mathrm{Ma}$. This level of change is striking (binomial test: $p=0.00004$ ). (In contrast to the trend in temperate Eurasia [Raia et al. 2011], increased hypsodonty generally is not involved.) The 8 Ma fauna records many continuing species, signaling a return to faunal stability and high species richness in the later Miocene, conditions that continue for artiodactyls to $6 \mathrm{Ma}$.

Rodents and artiodactyls both show a high rate of immigration in the middle Miocene, around $14 \mathrm{Ma}$ (Fig. 2). The culmination of faunal stability with high species richness among both groups around 14 to $12 \mathrm{Ma}$ includes persistence of residents and declining immigration. Small mammals show high endemism at $12 \mathrm{Ma}$, and the maximum endemism for artiodactyls peaks at $10 \mathrm{Ma}$. For the biogeographic area under study, the Indian subcontinent subregion shows: (1) an influx of faunal elements at about $14 \mathrm{Ma}$, (2) a middle Miocene interval of relative faunal isolation with many continuing residents and high endemism among rodents, (3) late Miocene decline in rodent diversity, while artiodactyls show turnover around 10 Ma followed by retention of residents and rebounding artiodactyl species richness in the next interval.

These observations stimulate intriguing questions. Did the middle Miocene Climatic Optimum (17-15 Ma) coincide with immigration and high species richness in the Indian subcontinent? Did the rapid cooling event of $\sim 14 \mathrm{Ma}$ (Holbourn et al. 2005) associated with lower sea levels facilitate dispersal as found by Faith and Behrensmeyer (2013) in the Pleistocene of southern Africa? Was the biogeographic subregion then relatively isolated, with little immigration but continuing long-lived lineages? Or were community niches packed such that few roles for potential middle Miocene immigrants were available? In the late Miocene, why do large and small mammals appear to show different patterns? As we refine the biostratigraphy, analyze taxon associations in faunal assemblages, and study the faunal records of adjacent regions, we hope to be able to answer these questions.

\section{Conclusion}

We established a set of definitions that enables 
discussion of faunal patterns observed for the succession of Miocene age terrestrial mammalian faunas of the Siwaliks. We defined what we mean by endemics, immigrants and residents, and we specified the biogeographic area of study, the Indian subcontinent. We analyzed Siwalik biostratigraphy at two-million-year intervals, with time slices $\sim 200000$ years thick.

Analyzing the rodent and artiodactyl components of faunal assemblages observed at each two-million-year interval, we tallied the proportions of endemics, immigrants and residents, enabling quantification of the contributions of each category to the fauna for each time slice. Long-term residents of assemblages ( $>2$ my residence) account for nearly one third of the total numbers of species. Of the new appearances, nearly half are endemics: $45 \%$ of the rodents, $40 \%$ of the artiodactyls.

These proportions do not hold constant throughout the Siwalik succession. Artiodactyls and rodents are both dominated by immigration in the early middle Miocene at 14 Ma. Around 12 Ma rodents show continuation of residents, but thereafter show decreasing diversity with resurgent immigration in the late Miocene. Artiodactyls also show stability in long-term residents at about $12 \mathrm{Ma}$, followed by turnover (increased immigrants and endemic appearances, but few residents) at $10 \mathrm{Ma}$. Residents again dominate a species-rich artiodactyl cohort in the late Miocene. Both groups show high species richness and dominance by long-term residents in the middle Miocene, but show different trends in the late Miocene. We sought complementary data to understand why.

This study focuses on events centered at twomillion-year intervals. Future analyses of endemism could be designed to study the record at finer increments of time, or to address other specific questions or times of interest for the Siwaliks. For example, time slice analysis at one-million-year intervals could reveal more temporally informative trends (but would certainly record greater proportions of residents). Research could be targeted to investigate the effects on community structure of a newly appearing exotic taxon that becomes widespread rapidly, such as Equidae, or to assess Siwalik faunal response at times of global climatic change.
Are there commonalities in community response across different geographic regions? Or, is each locale sufficiently unique in ecological character to yield novel outcomes? Comparisons within a region, such as Europe or Asia, could be made to test degrees of endemism at different geographical scales. What features appear to contribute to higher or lower rates of endemism? How do patterns for small and large mammals differ - or do they?

One of the properties of long biostratigraphic data sets from single areas is that portions of the record can be compared with each other, and can be used to approach difficult questions such as the role played in communities by endemism. Biostratigraphy holds the key to perceiving biogeographic detail in ecosystem evolution.

\section{Acknowledgements}

The long tradition of original research so successfully developed at Helsinki University, especially under the leadership of Mikael Fortelius, has inspired lines of research that we have developed for the rich Siwalik record. We thank Anu Kaakinen and Pirkko Ukkonen for the opportunity to show our admiration for this tradition of research. Our long-running field research program in Pakistan was made possible through collaboration with the Geological Survey of Pakistan and the Pakistan Museum of Natural History. Financial support has derived from the U.S. National Science Foundation, from the National Geographic Society, and from the Smithsonian Foreign Currency Program, with special thanks to Francine Berkowitz of the Smithsonian for enduring support of our research in Pakistan. Many of the ideas developed here were given life by spirited discussion with Erik Otárola-Castillo, Yuri Kimura, Catherine Badgley and Kay Behrensmeyer, and we benefited from constructive reviewer comments.

\section{References}

Badgley, C. \& Behrensmeyer, A. K. 1995: Preservational, paleoecological, and evolutionary patterns in the Paleogene of Wyoming-Montana and the Neogene of Pakistan. - Palaeogeography, Palaeoclimatology, Palaeoecology 115: 319-340.

Barry, J. C., Morgan, M. E., Flynn, L. J., Pilbeam, D., Jacobs, L. L., Lindsay, E. H., Raza, S. M. \& Solounias, N. 1995: Patterns of faunal turnover and diversity in the Neogene Siwaliks of northern Pakistan. - Palaeogeography, Palaeoclimatology, Palaeoecology 115: 209-226.

Barry, J. C., Morgan, M. E., Flynn, L. J., Pilbeam, D., Behrensmeyer, A. K., Raza, S. M., Khan, I., Badgley, C., 
Hicks, J. \& Kelley, J. 2002: Faunal and environmental change in the late Miocene Siwaliks of northern Pakistan. - Paleobiology 28 (Memoir 3): 1-71.

Barry, J. C., Behrensmeyer, A. K., Badgley, C., Flynn, L. J., Peltonen, H., Cheema, I. U., Pilbeam, D., Lindsay, E. H., Raza, S. M., Rajpar, A. R. \& Morgan, M. E. 2013: The Neogene Siwaliks of the Potwar Plateau and other regions of Pakistan. - In: Wang, X., Flynn, L. J. \& Fortelius, M. (eds.) Fossil mammals of Asia: Neogene biostratigraphy and chronology: 373-399. Columbia University Press, New York.

Casanovas-Vilar, I., Garcia-Paredes, I., Alba, D. M., van den Hoeck Ostende, L. W. \& Moya-Sola, S. 2010: The European Far West: Miocene mammal isolation, diversity and turnover in the Iberian Peninsula. - Journal of Biogeography 37: 1079-1093.

Costeur, L. 2009: Preliminary overview of regional endemism in European Neogene ungulates. - Bulletin de la Société Géologique de France 180(1): 17-25.

Faith, J. T. \& Behrensmeyer, A. K. 2013: Climate change and faunal turnover: testing the mechanics of the turnoverpulse hypothesis with South African fossil data. Paleobiology 39: 609-627.

Flynn, L. J. 2007: Origin and evolution of the Diatomyidae, with clues to paleoecology from the fossil record. Bulletin of Carnegie Museum 39: 173-181.

Flynn, L. J. \& Wessels, W. 2013: Paleobiogeography and South Asian small mammals: Neogene latitudinal faunal variation. - In: Wang, X., Flynn, L. J. \& Fortelius, M. (eds.), Fossil mammals of Asia: Neogene biostratigraphy and chronology: 445-460. Columbia University Press, New York.

Flynn, L. J. \& Winkler, A. J. 1994: Dispersalist implications of Paraulacodus indicus, a south Asian rodent of African affinity. - Historical Biology 9: 223-235.

Flynn, L. J., Downs, W., Morgan, M. E., Barry, J. C. \& Pilbeam, D. 1998: High Miocene species richness in the Siwaliks of Pakistan. - National Science Museum Monograph 14: 167-180.

Flynn, L. J., Barry, J. C., Morgan, M. E., Pilbeam, D., Jacobs, L. L. \& Lindsay, E. H. 1995: Neogene Siwalik mammalian lineages: species longevities, rates of change, and modes of speciation. - Palaeogeography, Palaeoclimatology, Palaeoecology 115: 249-264.

Flynn, L. J., Lindsay, E. H., Pilbeam, D., Raza, S. M., Morgan, M. E., Barry, J. C., Badgley, C., Behrensmeyer, A. K., Cheema, I. U., Rajpar, A. R. \& Opdyke, N. D. 2013: The Siwaliks and Neogene evolutionary biology in South Asia. - In: Wang, X., Flynn, L. J. \& Fortelius, M. (eds.), Fossil mammals of Asia: Neogene biostratigraphy and chronology: 353-372. Columbia University Press, New York.
Gentry, A. W., Solounias, N. \& Barry, J. C. 2014: Stability in higher level taxonomy of Miocene bovid faunas of the Siwaliks. - Ann. Zool. Fennici 51: 49-56.

Hausdorf, B. 2002: Units in biogeography. - Sytematic Biology 51: 648-652.

Holbourn, A., Kuhnt, W. Schulz, M. \& Erlenkeuser, H. 2005: Impacts of orbital forcing and atmospheric carbon dioxide on Miocene ice-sheet expansion. - Nature 438: 483-487.

Jacobs, L. L. \& Downs, W. R. 1994: The Evolution of murine rodents in Asia. - In: Tomida, Y., Li, C. K. \& Setoguchi, T. (eds.), Rodent and lagomorph families of Asian origins and diversification: 149-156. National Science Museum Monograph 8, Tokyo.

Liow, L. H., Fortelius, M., Bingham, E., Lintulaakso, K., Mannila, H. \& Flynn, L. 2008: Higher origination and extinction rates in larger mammals. - Proceedings of the National Academy of Sciences 105: 6097-6102.

Lomolino, M. V., Riddle, B. R., Whittaker, R. J. \& Brown, J. H. 2010: Biogeography, 4th ed. - Sinauer Associates, Inc., Sunderland, Massachusetts.

Mein, P. \& Ginsburg, L. 1997: Les mammifères du gisement miocène inférieur de Li Mae Long, Thaïlande: systématique, biostratigraphie et paléoenvironnement. - Geodiversitas 19: 783-844.

Peterson, A. T. \& Watson, D. M. 1998: Problems with areal definitions of endemism: the effects of spatial scaling. Diversity and Distributions 4: 189-194.

Qiu, Z. \& Ni, X. 2005: Small mammals. - In: Qi, G. \& Dong, W. (eds.), Lufengpithecus hudiensis site: 113-131 \& 308-318. Science Press, Beijing.

Raia, P., Carotenuto, F., Eronen, J. T. \& Fortelius, M. 2011: Longer in the tooth, shorter in the record? The evolutionary correlates of hypsodonty in Neogene ruminants. - Proceedings of the Royal Society B 278: 3474-3481.

Rössner, G. E. 2007: Family Tragulidae. - In: Prothero, D. R. \& Foss, S. E. (eds.), The evolution of artiodactyls: 213-220. The Johns Hopkins University Press, Baltimore.

Şen, Ş. \& Thomas, H. 1979: Découverte de rongeurs dans le Miocène moyen de la Formation Hofuf (Province du Hasa, Arabie Saoudite). - Compte rendu sommaire des séances de la Société Géologique de France 1: 34-37.

Simpson, G. G. 1965: The geography of evolution. - Chilton Books, Philadelphia.

Van der Meulen, A. J., Peláez-Campomanes, P. \& Levin, S. A. 2005: Age structure, residents, and transients of Miocene rodent communities. - The American Naturalist 165(4): E108-E125.

Wessels, W. 2009: Miocene rodent evolution and migration: Muroidea from Pakistan, Turkey, and northern Africa. Geologica Ultraiectina 307: 1-290. 